\title{
Analysis of Necessity and Feasibility of Enhancing Graduate Employability--Taking Korean as Example
}

\author{
Yong Yu \\ College of International Education, Hainan College of Economics and Business \\ yuyong163163@163.com
}

Keywords: Hainan higher technical and vocational college; the second foreign language; Korean; employment

\begin{abstract}
In recent years, Hainan higher technical and vocational education has developed rapidly, mading great contributions to the development of the harmonious socialist society. However, employment of the college students witnesses serious problems. Starting with enhancement of employmentability of Hainan higher technical and vocational college graduates, this paper analyzes and elaborates necessity and feasibility of offering the second foreign language in these colleges.

Since the Ministry of Education held the first national technical and vocational college meeting, launching and implementing demonstrative high technical and vocational college, facultyh training center and education center and other development, China has rapidly developed higher technical and vocational educaztion. Hainan has increased its higher technical and vocational colleges in quantity, enrollment, and teaching quality, cultivating applied talents for local economic development, making incalculable contributions to its coordinated economic development.

With the develoment of Hainan International Tourism Island and Free Trade Pilot Zone, Hainan will ewenhance its opening to the international community, making foreign language talents increasingly popular and cooperation and exchanges with the countries along "the Silk Road Economic Belt and the 21st-century Maritime Silk Road” increasingly extensive. It can be said that demand for vocational education and foreign language talents witnesses a "prime time development period."
\end{abstract}

However, employment of Hainan techniical and vocational college graduates remains unsatisfacory, suffering the following 2 problems:

First, positioning is unclear. A large number of graduates find it difficult to find suitable jobs, causing serious contradictions between supply and demand. The reason is their quality fail to meet production needs of various enterprises, or the needs of "world factory". Ultimately, they suffer deviations in their positioniong of cultivation objectives and models.

Second, orientation is unclear. Facing employment or advancement, the students need rational and practical course setting, focusing on extensive and sufficient ranges, globalization, senior applied knowledge and skills,technology and application. It is not proper to simply change the courses on the original basis. The second foreign language will surely play an invaluable role in "technology and application".

\section{It Is Necessary to Offer the Second Foreign Language in Higher Technical And Vocational Colleges for Employability of Graduates.}

\subsection{Hainan economic development and pilot higher technical and vocational colleges}

Hainan has been increasingly internationalized. Various languages of the world are no longer just discourse tools in interpersonal communication. More importantly, they serve as the only way to get familiar with advanced technologies and concepts. Higher technical and vocational colleges focusing on employment should constantly improve, develop and expand their foreign language teaching, making it an important perspective of education and teaching reform. 
In 2018, Hainan College of Economics and Business started to offer the Korean language course, requiring mastery of daily expressions, well received by students, especially those in Scholl of Humanities and Arts and School of Engineering Technology.

\subsection{Demand for "second foreign language" talents}

Since the beginning of the 20th century, English learning has been surging in China. Entering the 21st century, English is basically a required course in primary, secondary schools, colleges and higher education. In most cases, people regard "foreign language" as a synonym for "English". But now, people can not and should not regard English as the only foreign language since English is basically the second language in China, widely popularized, especially among those who have received secondary or higher education. Almost all college graduates understand certian English. Of course, few are competent in English professional application. Higher technical and vocational college students should be characterised by sufficient foreign languages and subsequent skills.

Xi'an FanYi University is a model of higher technical and vocational education, successful and competitive. Foreign language teaching proves its unique advantage and important part of its branding, indicating China's employment market has significantly increased demand for foreign language applications.

\subsection{Production requirements}

Offering the second foreign language in higher technical and vocational colleges is conducive to cultivation of compound talents. Constant integration of modern production technologies and sufficnecy of technical posts in production require multiple complex talents and skills, in particular talents of one or more foreign languages. Higher technical and vocational college graduates are generally not engaged in research, but in application of their knowledge in production. Mastering one or several foreign languages is a basic condition for application of their outsourced high technologies and a prerequisite for their successful employment. Almost all the technologies can be obtained in practice and production, but languages, especially foreign languages, mean a potential capability, requiring long-term studies, necessary communications, sound system foundation, achieving sublimation and improvement in production.

A student at Hainan College of Economics and Business was once indulged in computer games, frequently absent from class and resulting in poor performance, not interested in English learning. Afterwords, he began to learn Korean, getting familiar with some cutting-edge information of Korean computer games. Later, he studied in the Republic of Korea, majoring in animation, successfully transferriing interest into profession

\subsection{Requirement for cultivation of student harmonious values}

Today, China centers on the harmonious socialist society, making foreign languages an open sesame for employment, cultivating student comprehensive quality and ability to a certain extent, achiving progress and harmony. Contemporary college students increasingly favor the foreign culture and exotic matters. It is proper to make full use of this psychology to guide them for new foreign language learniung and healthy growth. In foreign language learning, students will adopt accedpt something new with “outward attitude”, proper to understand natural speakers' characteristics, especially advanced technologies and ideas. cultivating their values and world outlook to understand, accept and tolerate others, laying down a fine ideological foundation for their employment and future long-term development as required by the harmonious socialist society. 


\section{Practical and Feasible for Hainan Higher Technical and Vocational Colleges To Offer the Second Foreign Language}

\subsection{Feasible for higher technical and vocational college students to learn the second foreign language}

Compared with regular college students, higher technical and vocational college students suffer relatively weak foundation and basic learning ability. Language learning, especially foreign language learning is time-conceived, not suitable for every period of life. The college period is the most energetic and vigorous, laying down a fine foundation for foreign language learning. Higher technical and vocational college students suffer relatively weak learning ability and they seldom make full use of their free time. However, educating and guiding students to use their free time to learn the new foreign language effectively improve their learning ability and latitude.

Interest is the primary motivation for learning. Repeated educational examinations, especially college entrance examinations, have severely impacted their interests in basic cultural courses, almost eliminating their original interest in "outmoded knowledge". But they have strong desire to accept new things and expectations and confidence. The second foreign language is something new to higher technical and vocational college students, which will inevitably stimulate their interest in obtaining "new knowledge”, properly rebuilding their confidence.

\subsection{Feasibility of offering second foreign language teaching in higher technical and vocational colleges}

\section{(A) In terms of external development}

Nowadays, higher technical and vocational colleges are vigorously going global. Sino-foreign cooperative school-running facilitates cultivation of outstanding students, effectively enhancing college cultural quality, professional strength, and influence. Offering of the second foreign language contributes to foreign exchanges and cooperation, serving as an important channel for selecting international students.

Material life has been greatly improved. Sino-foreign cooperative school-running and students cultivating have been increasingly popular among students and their parents, providing financial guarantee for offering the second foreign language, improving college popularity and running capacity.

\section{(B) In terms of application of infrastructure}

Some training equipmewwnt and facilities require constant maintenance, repair and upgrading, characterized by large investment. However, offering the foreign language courses requires relatively low investment. Low specialization and elimination reduce idleness and waste of professional training facilities. Higher technical and vocational colleges can concentrate limited funds to relevant training rooms for series develoopment, forming complete advanced training systems, making quality and resources of training facilities fully utilized and efficiently shared, reducing costs of development and application, improving effect of practical teaching, savinge investment, and forming the low-cost advantage.

\section{(C) In terms of faculty}

Development of "double-competency teacher" teams witnesses a bottleneck in higher technical and vocational colleges. Offering the second language teaching can promote the formation of certain professional groups, collecting resources of similar and related majors, forming professional teacher quantification advantages and structural advantages. Flexibly referenced in professional teaching, it meets the needs of professional teaching, enhancing professional competitive advantages, reserving high-quality translation talents for the provincial people's government and local enterprises. Formation of school running characteristics in higher technical and vocational colleges requires long-term efforts in multiple aspects. The professional foreign language resource teams will rapidly integrate advantages of faculty, training, research, major and course develeoopment, forming concerted efforts and developing features and brands. 


\section{Conclusion}

All in all, development of Hainan higher technical and vocational education needs rational and correct orientation. Running of higher technical and vocational colleges centers on vocational education, focusing on the market, going global and modernized.

Offering the second foreign language teaching focuses on students and their employment, namely their immediate and realistic interests, their fundamental interests.

\section{References}

[1] Grant Henning, A Guide to Language Testing: Development, Evaluation and Research (USA), Foreign Language Teaching and Research Press.

[2] Yuan Gao and Fuyin Li, Ten Lectures on Applied Cognitive Linguistics by John Taylor (English Edition) (1 Disc), Foreign Language Teaching and Research Press.

[3] The CPC Hainan Provincial Committee, Hainan International Tourism Island Construction and Development Plan Outline. 